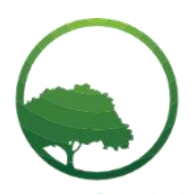

Research in Business \& Social Science

\title{
Effects of the challenges facing re-entry of women ex-offenders in Nyeri County, Kenya
}

John Mbai Muthee $\mathbb{( a )}^{(a)}$ Scholastic M. Adeli(b), Francis O. Barasa(c)

\section{ART ICLE INFO}

Article history:

Received 28 February 20

Received in revised form 05 April 20

Accepted 02 June 20

Keywords:

Effects, Women Ex-offender,

Incarceration, Returnee, Reentry,

Reintegration

JEL Classification:

K40, K38, K10

\begin{abstract}
A B S T R A C T
The comparative rate of women entering the formal correctional system and serving custodial sentences, both in prison and prison remand awaiting trial, is on the increase. This is accompanied by a similarly increasing number of women eventually exiting prisons annually. This study investigated the challenges influencing reentry of women ex-offenders in Nyeri County, Kenya. The study specifically investigated the effects of not addressing the challenges identified for women returning from prison in Nyeri County especially challenges connected to housing, employment, relationships, drug, and substance abuse as well as mental health after incarceration. This was a qualitative study adopting a phenomenological design. The site and respondents were purposively selected with snowballing being used to select the respondents to the point of saturation. This study made use of 41 women ex-convicts, 3 FGDs, and 9 key informants. Data were collected by use of semi-structured interview schedules. Results indicated that ex-offenders face various challenges upon release from prison. The effects of these challenges when not addressed the impact the individual self, their family, the community, and predisposed the ex-convicts to a high propensity for recidivism. Based on the findings it is suggested that the use of community corrections, adjusting prison training to market needs, and the use of victim-offender mediation can be better alternatives to incarceration.
\end{abstract}

() 2020 by the authors. Licensee SSBFNET, Istanbul, Turkey. This article is an open access article distributed under the terms and conditions of the Creative Commons Attribution (CC BY) license (http://creativecommons.org/licenses/by/4.0/).

\section{Introduction}

The purpose of this study is to examine the challenges women returning home from prisons face in Nyeri County; the effects of the challenges, how they cope with the challenges as well as remedial measures that can be undertaken. This is a generally neglected topic in the treatment of offenders. No written policies and practices exist in Kenya that addresses the difficulties faced by exoffenders, particularly women. No known qualitative studies focusing on challenges women returning home from prison face has been conducted in Kenya or Nyeri County

Within the field of criminology, ex-offender reentry and reintegration into the community are urgent topics of growing concern. Knowledge within this area has undoubtedly advanced with time, however research and empirical evidence is still not fully adequate (Maruna, 2010). Qualitative research is lacking in general, promoting and utilizing the ex-offender perspective in research may be able to alter and improve reentry policy and practice (Schlager, 2013). With this, it may be possible to shift the connotation of the dialogue regarding reentry from negative to positive. Ex-offenders typically follow a zigzag path. This means their life is usually constituted by periods of criminal activity and intermittency: they may be good for some time, but eventually fall back into the deviant lifestyle (Maruna, 2010). As a result, these individuals typically experience incarceration multiple times throughout their life. Therefore, reentry not only affects ex-offenders themselves, but their families and the community at large (Schlager, 2013). During reentry, issues of public opinion and stigmatization commonly arise and become problematic (Schlager, 2013). It is evident through this that conviction haunts an individual long past they have paid their debt to society.

In the United States has the highest incarceration rate in the world, surpassing nearly all of the developed countries, including those with repressive regimes such as Russia, China, and Iran (Alexander, 2010). According to the Bureau of Justice Statistics (BJS), over

* Corresponding author. ORCID ID: 0000-0001-8063-4764

(C) 2020 by the authors. Hosting by SSBFNET. Peer review under responsibility of Center for Strategic Studies in Business and Finance.

https://doi.org/10.20525/ijrbs.v9i4.699 
two million people make up the prison population in the United States (2013). Mulmat and Burke (2013) reported that one in every 100 adult Americans is behind bars. On average about 650,000 inmates return home from incarceration each year since 2013 and about two-thirds recidivate (Farabee et al., 2014). A criminal record calumniates the employability of a significant subset of Americans that want to re-enter the workforce after release. Thus, researchers view employment as a concern for all prisoners (Decker et al., 2015; Swensen, et al., 2014; and Nally et al., 2014). Reentry organizations recognize the critical role that jobs have in successful reintegration and offer programs that focus on job readiness (Flowers, 2013).

Upon release from prison, offenders face a myriad of challenges (Davis et al., 2012). These barriers become an impediment to rehabilitation and increase ex-offenders' chances of reoffending. Davis et al. (2012) note that the prison environment is markedly different from mainstream society. Upon release, offenders are plunged into an environment that is different from the prison environment and they struggle to cope. Furthermore, given the dynamic and ever-changing nature of society, ex-offenders who spend long periods in prison are released into an environment that is very different from their former environment before imprisonment. This poses a serious challenge for the reintegration of offenders.

A gap exists in the reentry literature regarding the difficulties that ex-offenders encounter throughout the job search process (Swensen et al., 2014). Many barriers constrain ex-offenders' ability to reintegrate into society, such as inadequate education and minimal job skills, but the most common barrier is finding a job with a criminal conviction (Decker et al., 2015). The unemployment rate for former prisoners is significantly higher than that of the general population (Nally et al., 2014). Unemployment is a complex problem for ex-offenders that continues to grow. A consensus exists in the reentry literature about the significance employment has on successful reintegration (Nally et al., 2014; Decker et al., 2015). Latessa (2012) argued that jobs help individuals develop self-worth and prosocial behavior.

In South Africa there is limited literature on offender reintegration and rehabilitation (Singh, 2016). Similarly, fewer studies have focused on the process of offender reintegration globally (Davis et al., 2012). Such a body of knowledge is critical to ongoing efforts to support offenders and society as part of a comprehensive crime prevention and reduction strategy.

In a study done in Kenya by Kaguta (2015) majority of women serving imprisonment possess low levels of education, are house wives and casual workers, single and separated. Their family is composed of two children and usually they have no training at all. In Kenya, the crimes leading to imprisonment of women include theft, handling of stolen goods, drug trafficking, assisting and concealing criminals and local brews. Other crimes include murder of intimate partners such as spouses/children, neglect of children, and assault leading to grievous bodily harm (Kaguta, 2015). In Kenya as of 2016 the population of women in prison was $7.4 \%$ of the total prisoners according to Kenya National Bureau of statistics (Statistical abstract, 2018). In Kenya, as of 2012 majority of the female prisoners (84\%) were aged above 21 years; an indication most of them had their own families and dependents. After serving prison, it is expected that the female offender will re-integrate back into society and become a better person. Part of the Kenya Prisons Service functions according to the Kenya Borstal Acts Caps 90 and 92 (Republic of Kenya, 1963) is to ensure smooth transition from prison into society. Reintegration for Ex-offenders is however faced by a myriad of challenges which further produce several impeding effects towards reintegration.

The number of offenders leaving prisons and getting back to the communities has increased globally. Sometimes these ex-offenders re-enter the societies without any supervision or reintegration follow up interventions (Stohr et al.,2009). Women returning home back into their communities encounter several challenges. For Muthee (2019) these challenges include housing, employement, broken relationships and mental health. The effects of these challenges when not addressed are not only felt by the returnees themselves but it also disturbs their families and communities. Failure to address these challenges is actually akin to a silent extension of imprisonment. This paper looks at how the women returnees view themselves as well as how their families and communities view them amidst the challenges encountered upon release and reintegration back in society.

\section{Research Methodology}

This was a qualitative study with a phenomenological design based on the fact that it is common in criminology research (Crow \& Semmens, 2007). The study was conducted in Nyeri County, Kenya and respondents drawn from all the sub-counties and cognizant to age and crime-type differentials. Majority of the study respondents had been released from Nyeri women prison which is part of King'ong'o Prison located in Nyeri County.

The research investigated 41 women who had been incarcerated either in a prison or remand prison for a period exceeding three months and had been released within a period between three months and six years prior to the interview. These ex-offenders considered Nyeri County their residence. The narratives were generated by interviewing female women ex-offenders and nine key informants comprising of the prison chaplain, prison officials, government and community leaders. The Key Informant Interviews (KII) was conducted among experts who on regular basis interact with women in prison and exiting prisoners as well as their families. Other narratives were made from three Focused Group Discussion raised from three cohorts namely family members of ex-offenders, prison welfare staff and eight select Christians conveniently picked from each of the sub-counties forming Nyeri County.

Snowball sampling or chain referral sampling was adopted in gathering the data. Through working with the local administration and CARITAS Nyeri who had some contacts, the survey sought to reach out to the identified ex-offenders. CARITAS Nyeri, is an 
initiative of the Catholic Church in Nyeri, which has had a Restorative, Justice and Empowerment programme (RJEP) strategy for both men and women exiting King'ong'o prison regardless of their religious affiliation serving Nyeri and parts of Laikipia Counties. Between 2013 and 2015 the programme focused on rehabilitation of ex-offenders but from 2015 to its closure in December of 2018 the welfare of the victims was also factored through Victim Offender mediation (VOM) initiatives.

Snowballing exercise was conducted until saturation was reached.

The research employed qualitative research methods of data collection through In-depth one-on-one interviews and Focus Group Discussions (FGDs). Qualitative data was processed through content analysis and analyzed thematically.

\section{Literature Review}

\section{Theoretical Studies}

According to Larner (2017) women practice multiple roles such as taking care for children, family chores e.g. farming, housekeeping, taking care of the sick and the elderly. Successfully reintegrating women back into their societies is therefore a great advantage to families and cost saving when recidivism is reduced. An appropriate theoretical orientation can inform improvement of both prison based and community corrections. A theory assists to explain and observe regularities and relationships between variables as well suggesting potential problems, predicting facts, assisting in narrowing down the facts and helping to point out knowledge gaps in a study (Abraham, 1982).

\section{Labeling Theory and Social Bond Theories}

Grommon (2013) states that existing literature on prisoner reentry is a theoretical and depend mostly on unclear patchwork of existing theories of crime. Reentry programs have largely been shaped by four specific emphases namely social control, social development, systems of supervision and the immediate transitional experiences after release.

Labeling and the social bond theories were selected to provide a theoretical framework for this study as they have a symbiotic relationship which supports either unsuccessful or successful reentry of women ex-offenders. The two theories selected are microsociological theories and fit well with the general qualitative method adopted in the case design study of this research (Jupp, \& Jupp, 1989). The theories capture the reentry process to periods predating their incarceration, during imprisonment and periods after imprisonment thus a holistic theoretical underpinning.

\section{Labeling Theory}

Labeling theory addresses the societal reaction to outlawed behaviour rather than the causes of crime and how this reaction affects the rule-breaker and why they occur (Miller, 2009; Triplet and Upton, 2015). According to Tierney (2009) the origin of the labeling theory is traced to the interests of sociologists in the United States and Britain in the 1960s. American sociologist Howard Becker is its main proponent. The sociologists had interest in crime and deviance. Labeling theory has been impacted by symbolic interactionism (such as Cooley 1902 and Mead 1934 and Blumer 1969), phenomenology and Marxism theoretical influences. The impact of symbolic interactionism contribution to the labeling theory has however been mediated by the works of Tannenbaum (1938) in his concept of dramatization of evil which was the first to apply the concepts of symbolic interactionism to criminal behaviour. This was later supported by Lemert (1967) who saw primary deviance as an outcome of social, psychological, cultural and physiological processes (Miller, 2009). Miller (2009) further sees the works of Becker (1963) as providing the key pillars of the labeling theory. The label and stigma for Becker vary from individual offenders and the victim. Later the labeling theory was developed by Shur (1971) and Cohen (1995) in their concepts of stereotyping and amplification respectively. The theory acknowledges the existences of many cultures or subcultures and moral relativism. In regard to criminality Becker's (the chief proponent of labeling theory) argument is that "the deviant is one whom that label has been successfully applied; deviant behaviour is behaviour that people so label....there are differences between one society and another regarding what is considered to be deviant" (Tierney, 2009, p. 90)

The implication of this perception is that deviance is a social construct which has both social and psychological outcomes for those defined as offenders and for their subsequent behaviour. Sometimes offenders opt to behave as so labeled thus recidivating.

The labeling theory or the societal reactions approach acknowledges the place of power, both formal as in the Criminal Justice System and informal power such as by families and communities in the definition of crime and criminals (Winfree \& Abadinsky, 2003; Siegel, 2010). The criminal is actually one who has been successfully labeled by the social group (Barlow \& Kauzlarich, 2010). According to Winfree and Abadinsky (2003) and Siegel (2010) labeling theory situates the role of power in definition of crime and criminals and captures the societal responses to each of them. Labeling theory also relates to conflict, symbolic interactionism and feminist theories which have tacit implication to the study of women returning home from prison.

For Winfree and Abadinsky (2003), Barlow et. al. (2010), Triplet and Upton (2015) and Williams (2012) labeling theory explains the role of social institutions in allocating people, their actions, beliefs and values some negative reactions such as criminalization. An allocation of a criminal identity status is actually one that is difficult to social-psychologically shed. Unfortunately, the labeled person(s) occasionally reshape their behaviour based on societal reactions and react to society on account of this negative label 
leading to secondary deviation. Securing a job or housing, stigmatization by families and communities for example, is for many exoffenders compounded on account of a criminal labeling.

Labeling is a byproduct of a four-step process which involves stereotyping or biased and negative generalization about a group or individuals; retrospective interpretation or looking into the history of a person for hidden indicators explaining the present behaviour particularly the negative; negotiations between the labeled and the labelers on the label through the charge, plea and sentencing and lastly role engulfment which is the way societies react to individual considered criminal. It is also the apex of the other three processes namely stereotyping, retrospective interpretations and negotiation (Winfree \& Abadinsky (2003).

According to Miller (2009) the Socio-psychological effects of a label is key to the labeling theory. Indeed even a formal label may deny lawful opportunities such as education, employment and marriage. It may be for this reason that the adherents of the labeling theory propose a public policy which strives to reduce stigma connected to being labeled a criminal through decriminalization, diversion, deinstitutionalization, and due process guarantees (Winfree \& Abadinsky, 2003). This is the direction taken by this study if successful reentry is intended. Sensitizing formal and informal social institutions such as families, churches, communities, government and political leadership to drop the negative status symbol of ex-convicts and accepting ex-convicts back into society is the single most important request that was proposed by majority of respondents and FGDs in the study to help them in successful reentry and reintegration. This is only attainable through strengthened bonds to the society and its acceptable norms as discussed in the social bond theory.

\section{Social Bond Theory}

Bost (2010) explicitly clarifies that the original intent of Hirsch's Social bond theory (1969) was to explain serious and violent crime among the youth. Bost (2010) further finds that classical criminology and sociology, Durkheimian concept of power and the impact of social governance on social conformity, Hobble's conviction that creating community and conforming to social norms has a social origin, have contributed to Hirsch's theoretical ideas.

Travis Hirsch's social bond theory is a social process theory which emphasizes that deterrence to crime is a major dependent of the totality of the social and physical environment forces that connects a person to the society and its moral constraint (Barlow et al., 2010; Siegel, 2010; Winfree \& Abadinsky, 2003). For Bost (2010) and Winfree and Abadinsky (2003) man's propensity to crime is markedly reduced through bonds of affectionate to social institutions such as the family and religious formations. The social bond involves attachment to conventional others (like parents, peers, teachers, friends), commitment, involvement and belief or value system and is nurtured in early childhood, extends to early life and adolescence and is affected both by the strength and the stability of the bond. Crime happens when any of these bonds is weakened. The theory permits exploration of differences in rates of crime between men and women and also the criminal rate differentials amongst ethnic and racial groups.

According to Bost (2010) the social bond theory is anchored in four interconnected key elements namely attachment to significant others; commitment to conventional behaviour; involvement in conventional activities and belief in the societal normative system. Attachment in the social bond theory refers to affection and sensitivity to members of the social group especially parents, peers and teachers. Absence of attachment leads to lack of internalization of both norms and values and subsequently a sentence of freedom to deviate. The second element is commitment which entails investing in conventional norms and rules for example by not engaging in adult activities like smoking, drinking and sex but rather having positive educational and occupational dreams. Indeed personal achievement positioning, academic and career expectations and entry into adult status are the three key pillars which define commitment. Involvement is the third element and basically involves the level of active membership in conventional activity such as time spent with friends or recreation and avoidance of idleness. Fourth and last element is belief in socially approved values and a rejection of unconventional values as engaging in crime requires one to disregard their moral beliefs (Bost, 2010; Siegel, 2010; Winfree \& Abadinsky, 2003).

Building pro-social bonds, participating in crime prevention conventional activities and repairing of earlier social bonds or even creating new social bonds has implications for reentry. Furthermore needs assessment and identification of specific strengths and weaknesses for construction of intervention is made with part placed on the individual and partly on others. The individual's external environment such as one's social ties, networks and institutions actually become the principal focus of intervention for crime desistance (Grommon, 2013

This theory best captures the reentry and reintegration process indirectly from the ex-offenders perspective but more extensively on their external environment. This is consistent with the labeling theory's key principle that others, more than the individual ex-convict, contain the power to laying structures for successful reentry and reintegration.

In summary avoiding labeling others as criminals and creating intimate ties with ex-offenders is the best pathway to reentry, crime desistance and re-integration. If the criminal label is dropped and social bonds strengthened the challenges, the effects of the challenges, the coping mechanism, practices and policies will be friendlier and supportive to reentry. Anything to the contrary makes reentry an uphill task.

\section{Empirical Review}


Offenders returning home from prison face numerous challenges. This section however only addresses worries linked to employment, housing, relationships, mental health and drug and substance abuse in relationship to the reentry discourse.

\section{Employment Challenges}

Employment involves a contractual relationship between two parties where one party is employed and the other is the employer in exchange for payment or job done. To be employed implies being in paid employment for salary whether in money or kind as well as being in self-employment such as private business or farm where profit in cash or kind is generated (Acocelle, 2007). According to ILO resolution of 1982 unemployment have tripartite indicators which include having no work with a formal or informal pay, availability for work, and searching for a job. The causes of unemployment include economic recessions, lack of necessary skills, experiences and education (International Labour Organization (ILO), 1982).

Giddens (2009) sees employment as a significant social issue which shapes the socio-economic development and stability of societies. For him Joblessness or increased un-employment (as happened in many African Countries following the introduction of structural adjustment programs of the late 1980s and early 1990s by the Bretton Wood institutions) has insurmountable implications for people particularly the poor. Indeed, socio-economic issues affect women differently from men as was seen with the collapse of masculine jobs such as in the coffee industry during the late 1980s and 1990s in Kenya. Actually, 60\% of women actually don't have a fulltime job at the time of arrest contrasted to $40 \%$ for men (Petersilia, 2005). In Kenya, the situation may be worse as women are grossly under-represented in all sectors of formal employment and only dominate the informal sector employment (KNBS, 2017). Lack of unemployment and stable source of income create a propensity to criminality as women seek to fend for themselves and their families.

The challenge of employment for ex-offenders is compounded by several factors which however should be considered within the context of general national unemployment rates and offenders' poor formal education rates (Larner, 2017). Unemployment is linked to stigma, likely erosion of job skills and social connections, preparation for mainly low-skills and market unattractive jobs through the in-prison programs, low education and vocational training levels, limited work experiences, early dropping out of school and general illiteracy. Lack of technological skills and access to internet or newspapers where jobs are advertised, low work enrollment in the periods preceding arrest and incarceration, age of arrest and release, and previous connection to substance abuse extend the list (Harris, 2015; Losel, 2012). Other factors that may limit employment opportunities include marital status, and presence of minor children (Kilgore, 2015). The strain associated with failure to get a job is graver for women as they are likely to have had low educational level and joblessness prior to arrest and incarceration. Even when they get and keep a job, women are not well remunerated as to meet their day-to-day needs and this makes them turn to illegitimate means such as drugs or prostitution to economically survive (Kerley, 2013). This situation is worse in a poor economy such as Kenya and where a sizeable number of women must raise and support families alone.

The burden of looking for a job is worse in countries, such as the USA, which impose legal restrictions pertaining to job acquisition list for ex-offenders (Cook \& Olivier, 2013; Kerley, 2013; Melissa, 2012; Petersilia, 2005). In Kenya for example; the requirements for chapter six of the Constitution concerning integrity for job seekers has been interpreted to include police clearance, Higher Education Loans Board (HELB), Credit Referencing Bureau (CRB), Ethics and Anticorruption Commission (EACC) and Kenya Revenue Authority (KRA) tax compliance certificates for job applicants. This shuts many ex-convicts from genuine job enrolment regardless of their other qualifications as the request is intended to raise any criminal history.

\section{Housing Challenges}

Reentry of ex-convicts is confronted by an immediate need for shelter upon release and exit from the prison gates. The following paragraphs explore the burden faced by ex-convicts in trying to find housing after some period of absence from home. The concept of housing is used by Sidel̦ska (2014) in reference to a real estate or part in a building which is used for dwelling purposes. The type of building is not important in defining a dwelling but rather that the building is used for human residence (Swason, 2008).

Housing is one of the most basic human needs and carries implications for health, social welfare and individual productivity regardless of socio-economic class, race or ideological affiliations (Okafar, 2016). The practical nature of the housing challenge in the US is extended to include problems associated with quality and affordability of decent housing (Freeman, 2003). Harris (2015) observes that women constitute the highest number of returnees who are flatly homeless and living in temporary shelter. This is because there is no chance for prior housing arrangements before release nor do they find family members to stay with after release (Kerley, 2013).

Herbert (2014) further observes that spending a sizeable budget of one's income in housing, overcrowding and lack of decent housing define housing insecurity. The correlation between homelessness and offending behaviour can become an ongoing cycle. In this cycle of events spending time in prison increases the risk of homelessness, while a lack of stable accommodation increases the likelihood of offending and reoffending.

Ex-offenders face difficulties in accessing housing and its stability because of prejudice and discrimination on account of a criminal label as well as the legal barriers which limit access to public funded housing (Clow, Ricciardelli, \& Cain (2012). In some jurisdictions, blanket screening policies and rules discriminate against public housing entitlement for those with a criminal history for fear it would affect other tenants (Melissa, 2012). 
Hattery and Smith (2010), Herbert (2014) and Nathan (2015) indicate that secure or stable housing is considered as the single most pressing and immediate need upon release and an indispensable pillar for successful community reentry. Studies that interrogate housing challenges for former prisoners are however few. According to Gunnison et. al. (2016) the housing challenge is experienced differently and deeply by women leaving prison and going home. Women, unlike men, require housing not only for themselves but their dependent children. Sadly, even when women find housing more often than not it is in poor neighborhoods where chances of getting employment are limited.

Women would likely face greater challenges acquiring decent housing following a criminal record. Patriarchal cultural structures and stereotypes still limit property ownership such as land and houses to men especially in the rural settings. Women leaving prisons therefore have challenges getting place to call home upon release from prison.

\section{Relationship challenges}

Mclvor (2004) notes that how women relate to their families, friends and partners, neigbourhood, community and society is important to reentry, desistance from crime and successful reintegration. Successful marital and family relationships provide emotional support after release from prison, the motivation to succeed, economic help, finding work, desistance from drug use and reduced recidivism. According to Visher (2004) families play a significant role in the reentry and reintegration process. Further, it is observed that strategies and resources which enhance the contribution played by families both in prison and after prison experiences be supported. Women encounter diverse family structures and friendship relationships on reentry. Women returning home find greatest support in their own mothers while men have both their mothers and intimate female partners for support (Hattery \& Smith, 2010).

Ex- offenders also discover that their families have had significant changes while they were away in prison. For example, studies have indicated increased personal and social vulnerabilities that may include unhealed familial ties such as between spouses and exoffenders, and familial ties between children, spouses and ex-offenders, and un-mended family conflicts (Mowen \& Visher, 2015; Dolwick, Crawford, Fields, Smith, Harris \& Matson (2014).

Violent crimes against intimate partners have been reported (White, 2002). Studies show that women are at greater risk of being harmed by an intimate partner than by a stranger (National Center for Health Statistics (NCHS), 2013). Harris (2015) argued that failure to sufficiently deal with intimate partner violence during prisoner reentry could place victims of domestic violence in continued danger and increase the formerly incarcerated individuals' risk of returning back to prison. Women returning home normally have broken relationships with the partners they had prior to imprisonment and creating new intimate relationships is impeded by the criminal tag.

\section{Mental Health Challenges}

The World health organization (WHO) defines health broadly as "a state of complete physical, mental, social well-being and not merely the absence of disease or infirmity" (World Health Organization, 1946.). This definition was adopted by the International health conference in 1947

and 61 member states were signatories. Health was recognized as a social and personal resource for every daily life by the Ottawa Charter for health promotion in 1986 (World Health Organization, 1986). The World Health Organization (2001) defines mental health as follows;

A state of wellbeing in which every individual realizes his or her own potential, can cope with the normal stresses of life, can work productively and fruitfully, and is able to make a contribution to his or her community. It is related to the promotion of overall health, the prevention of disease, and the treatment and rehabilitation of people negatively affected by illness (WHO, 2001, p 1)

Common mental disorders are characterized by a complex web involving abnormal thoughts, perceptions, emotions and relationships with others. They include depression, bipolar affective disorder, being schizophrenic, psychosis, dementia or memory loss, intellectual inabilities and autism (World Health Organization, 2018).

According to Petrillo (2007), James and Glaze (2006) and Byrne and Howells (2000) female prisoners manifest more serious mental health issues when placed in a comparative scale with their male counterparts or other women in the general community. The complex impacts of mental illness can be significant motivation in women offending and may frustrate rehabilitation efforts. Mental health challenges may also impede women ex-offenders from accessing programs, services and other supports necessary to successful reintegration after release from custody. Mental health issues have a gendered differential. Histories of physical and sexual abuse together with separation from family and children worsen the case of mental health in women prisoners (Pogorzelski, Wolff \& Blitz, 2005; Bonta, Rugge, Scott, Bourgon, \& Yessine, 2008).

\section{Results and Discussion}

The following personal descriptions were generated from the general profile of the research participants. The women's age ranged between 22 to 70 years old. The overwhelming majority - 39 of them had been incarcerated in Nyeri women prison, one in Nanyuki and Murang'a women prison respectfully. 11 were currently married, 10 widowed, and 14 separated. 6 had never been married. Over $70 \%$ of returnees had 3 or more children in their homes, $62 \%$ indicated they had education up to primary level, about half of the ex- 
convicts had committed crimes related to 'crimes against persons' while possession of dangerous drugs was (17\%)and theft of stock $(10 \%)$.

Majority (79\%) of the ex-convicts interviewed spent three years and below in prison with only $19 \%$ of them detained for more than 4 years. All ex-convicts were very happy upon release and were very excited to be re-united with their children and to a good extent their families. The ex-offenders had received some training while in prison which included counselling, tailoring, knitting, embroidery, baking, organic farming, detergent making, hair dressing, bead works and crocheting (duvet, dolly and carpet making). Two women ex-offenders strongly declined to be interviewed on the basis that their prison experiences were too traumatizing to be recounted. Summary of the profiles of the respondents is given in Appendix I attached.

\section{Discussions}

The study specifically sorts to establish and analyze the effects of not addressing the challenges facing women returning from prison in Nyeri County. The effects were studied in regard to their impact on the individual self, their families, the community and in regard to recidivism susceptibility.

Failure to acquire housing and employment as well unrepaired relationships produced different effects on individual self after imprisonment depending on each ex-convict's circumstances. Other effects on the ex-convict resulted from unattended mental health, drug and substance abuse struggles were diverse. Some had walked out of prison feeling better, more determined to face challenges ahead while others were bitter, unsure of the way forward or even desperate. Some of those who were positive felt they had learnt something from prison life and were determined not to return to prison again, others had been changed by the counselling offered and wanted to transform themselves and move on with life.

Dorcas, who was in prison for almost four years indicated that; "although the journey was tough, I thank God for the lessons and knowledge I picked from prison". Some ex-convicts and remandees to the contrary left prison feeling bitter about the time they had wasted in prison, the difficult life at prison and lack of freedom. There were some who however continued to experience uncertainty especially on unemployment, housing and relationship much far after leaving prison. This made them to live a stressful life especially those who had been released from remand prison and were still waiting for the conclusion of their cases. Jehosheba, who had been in prison for two years, lamented "I still remain disappointed as I had to start a life again"

Lack of employement and Housing were indicated to have long continued to affect women ex-convicts, dooming them into a life of poverty and obscuring their reintegration. Prior to imprisonment a majority of the women returnees were mainly casual labourers due to low education levels with only two (4.87\%) having been employed in the formal sector and four (9.75\%) owning small businesses like salon, selling second hand clothes and kiosks. Four (9.75\%) were however lucky and got formal jobs such as cooks, adult education teacher while another joined a milk processing company. Incidentally, all the four indicated they still keep as a secret their criminal history and their places of work are away from where they committed the crimes. The ex-convicts who had found meaningful jobs on release appeared to have weathered the storms associated with incarceration.

One key informant in supporting the above had this to say;

Some of the women ex-convicts were forced to remain poor, doing menial jobs and hawking. Some also end up in the streets. Those not accepted back by their spouses go out and rent out houses either with the kids or by themselves.

What strongly came out from the FGD discussion was that the jobs common to most of the returnees were to serve as house helps and bartenders. This seemed an easier option for them especially those having housing problems.

The above discourse reveals a mixed efficacy of the prison system to prepare convicts for release and integration. Majority of returnees live in abject poverty as they cannot access jobs in the formal employement sector and even when they do their criminal histories must remain secret. The low education levels of the returnees, poor work skills, their criminal history, interruption of social and family capital support to job finding actually worsens their predicament (Crow \& Semmens, 2007; International Labour Organization (ILO), 1982; Pager, 2007). The case is worse given in Kenya the majority of the unemployed population is aged below 35 years and $64.5 \%$ of them are women (KNBS, 2018). Lack of employement has potential to perpetually affect the women exconvicts as employment acts as a gate way to ex-offender productivity, caring for their families, development of life skills and boosting their self-image and social capital and successful reintegration and reducing propensity for recidivism (Nathan, 2015; Petersilia, 2005; Wodahl, 2006).

Before incarceration 18 (43.90\%) respondents owned their houses, 17 (41.46\%) were in rented houses and $6(14.63 \%)$ stayed with their relatives. The number staying with relatives however doubled to $12(29.26 \%)$ after release, while that staying with families reduced to $16(39.02)$ and to $13(31.70 \%)$ for those staying in rented houses. Relatives, especially mothers and sisters, provided accommodation to the ex-convicts soon after release before they rented their own houses and far away from home. This was supported by one KII, who indicated that some women continued to face housing challenges many months after their release and the church had to step in and offer an upkeep stipend;

The Church sometimes has to offer help with rent of about five months for some of the women long after they left prison.. there is no policy of their stay after exiting the prison gate, and they are left to themselves, their families, religious groups or well-wishers. 
The prison system evidentially has no care for where the convicts go to after exiting the prison gates. The ex-offenders are flatly left to find their way home, to their relatives or sometimes are briefly accommodated by a friendly ex-convict whom they may have met during their incarceration. Others prefer to rent a house away from where they are not known. This concurs with Harris (2015) observation that women constitute the highest number of returnees who are flatly homeless and living in temporary shelter. This is explained by Kerley (2013) who states that there is usually no chance for prior housing arrangements before release nor do the women ex-offenders find family members to stay with after release.

Concerning the mental health of the ex women convicts, one KII, was quite positive about their mental health and had this to say;

Anxiety is there but it doesn't affect women as much. Women, married or single, in this part of the country are generally likely to be the family bread winners...so they tend to be more focused than worried on whom to provide for them after prison.

This implies that with some bit of support especially with housing women in Nyeri can easily find their footing and start life again after incarceration.

There was however a strong conflicting argument amongst the community FGD members that long after prison release women still felt discriminated, depressed and experienced suicidal thoughts. This is what came out from one FGD;

Lack of self-acceptance.....Sometimes feelings of demeanor and guilty for the crimes committed and if not well received by the family and community they can engage in self-harm".

This was echoed by the family members FGD who said; "they have a negative self-image about themselves and could easily commit suicide if not well handled by the family and community".

Anxiety, stigma and discrimination, lack of self-acceptance, feelings of guilty and negative self-image characterize the mental health status of the returnees and this affects their integration. Indeed, separation from family and children has been known to worsen the case of mental health in women prisoners (Pogorzelski et. al., 2005; Bonta, et. al., 2008). When not addressed mental health issues pose serious challenges in the reentry and reintegration process back into communities for many ex-offenders (Travis, 2001) and could lead to harm for self or others (Melissa, 2012; Davies, 2011).

The findings thus present a double sided outcome on how women ex-convicts are affected by their challenges following imprisonment. Whereas some see it as a learning opportunity that provided new opportunities others are unable to comprehend why they had to face the ignominious and wasteful years in prison. This later group views their reentry and reintegration negatively while those positive on the whole experience have better reentry and reintegration prospectus. This was well stated by the prison welfare staff FGD that;

Those who accept their criminal past easily face their challenges such as unemployment or broken relationships and accept to move on with high self-esteem. ...but those who never accept themselves and their conditions normally live with very low esteem. Same case happens for those who feel they were falsely accused... they feel they have lost their dignity and time.

Family members are the secondary carriers to the effects of the challenges encountered by ex-offenders re-entering back into societies. The experiences faced are however sometimes nasty. The family members FGD interviews said;

Their brothers look at them negatively and with stigma... they are sometimes hated by their families and communities... families and communities are usually divided between those who support the ex-convict and those who have a very negative attitude towards them depending on the crime they had committed.

Another finding is that families of ex-convicts are stigmatized on account of their member's incarceration especially those who continued to live within their midst for lack of employement and housing. Even when the ex-convicts moved out to rent houses elsewhere their families continued to be linked with their bad behaviour. One KII emphatically stated;

In most cases, once you enter the jail, you are a bad person. People avoid you, your children and your family. There is a case where we went looking for children from a mother who had committed murder; her children stated they had been socially discriminated on account of their mother's action.

The effects of unaddressed challenges to the family include separation (family break up), extra burden in feeding and housing the exconvicts and their immediate dependents, bitterness among the victim's family and stigma and discrimination of the ex-convict's families. Ex-convicts who haven't acquired a job and their own housing appear to impose an unnecessary burden to their families such as having to support their children. This breeds rejection, division amongst the family members and stigma.

Renewing relationships with family members and friends is actually difficult and leads to isolation for ex-offenders (Olphen et al, 2009). Journeying back home and the associated challenges affect women heavily as more often than not they are single mothers sometimes unable to provide basic needs to their dependent children (Mumola, 2000).

The community is also affected when challenges faced by women returning home are not addressed by mainly feeling insecure upon return of the ex-convicts. The community moreover plays a bigger role in stigmatization and discrimination of the ex-convicts socially, economically and spiritually. Merab (not her real name), who was in prison for forgery stated that the community habitually 
discriminated and associated the ex-convicts with any crime occurring in their neighborhood however long after release. She stated thus;

There is lack of acceptance in the community and bad talk especially by fellow women, if anything is lost from chicken to anything else I am usually treated as the suspect. When I dress well or the children build me a house they said it was stolen money. I am labeled a thief and a prostitute. I am referred to as the woman who left prison.

Indeed two outstanding effects were manifest when and where communities encountered ex-convicts known to them but were jobless, lacked housing and relationships remaining broken. These are stigma and tacit extension of punishment. The experience by KII, prison chaplain was

Some communities can be hostile to offenders upon release and even after...but to avoid this hostility the national government can use the chiefs and assistant chiefs to reconcile ex-offenders with their communities. The Members of County Assembly at the County government levels can also be useful in the Victim Offender Mediation(VOM) process.

Community extension of punishment long after prison is an impeding experience for women wanting to find new intimate relationships and probably marriage. KII, Caritas officer, observed "Those who are not married find it extremely hard to get married within their area unless they go somewhere else... it would take a lot of convincing to make people believe that they have changed".

This observation was shared by the FGD by the Prison welfare staff that;

After completing the sentence, you are cleared and should go back to normal life. That is how the system should work. But there is still a bigger risk owing to stigmatization as people continue to punish the ex-convicts for sentencing already served. The family need to be uplifted and government need to see how the community can be educated to stop this

The communities FGD equally observed that unless families of the returnees accept and appreciate them, communities remain negative and sometimes banish them especially those who have dead parents, are separated or have no houses of their own. The local thinking is that "prisons are for men and not women. This is the norm since colonial times and it cannot be viewed different even today".

The worst response from the community to the returning offenders is stigmatization. The case for women is sadder since they are affected more by labeling, stigmatization associated to imprisonment and the subsequent feeling of shame (Dodge \& Ogrebin, 2001).

In general terms recidivism means a relapse into crime and criminal lifestyle or activities by an offender who had at some time or severally been arrested and punished through the formal criminal justice system (Cook \& Olivier, 2013; Tenibiaje; 2013). According to the community and the probation officers, recidivism is not common among women returnees in Nyeri County. A probation officer in Nyeri observed "Recidivism is uncommon among females....in fact most of these women do not come back. The rate is very low and sometimes you can go for months without any". This observation was collaborated by the research findings among the ex-convicts as majority of them (90\%) had stayed out of prison for more than one year since release, and only $20 \%$ had recidivated in the past.

Asked about fellow women prisoners whom they encountered in prison and those who had recidivated, the following reasons were advanced as the causes of their crime and recidivism: Lack of financial support(poverty), temper, family conflict and separation, peer pressure, greed for money and desire for better life, influence of alcohol and drugs, joblessness and false accusation. One of the exconvicts, Jeneth, narrated how she had a friend who kept of recidivating because of drugs thus "I had a friend from prison using bhang and when she got out, she went back to selling it for another person. So she used to get caught but the owner goes scot free".

One prison officer also observed some of the ex-convicts also recidivate willingly as a way of running away from the harsh realities of life outside prison too. In support of her narrative, the officer narrated;

Some come back willingly so that they can have some help. At Shimo la Tewa we used to have a lady who always came when she was 7 months pregnant so that she can get health care at prison. She was a carrier but wanted the prison to sustain her at birth and the child.

From the research it was noted that majority of the recidivists were mainly those involved in drug related crimes and assault. The implications of these findings is that recidivism rates amongst subjects of the study is low, probably based also on the nature of the crimes committed, fear for re-incarceration and the generally low crime rates amongst women. Given recidivating was linked to sale of drugs and substances it can also be interpreted that the usage of drugs and consumption of alcohol is prevalent in the County. Caution must however be observed that the consumers of drugs and substance abuse are mainly men and that women's engagement in the trade is only as sellers or traffickers in order to support their families. The difficulties of life brought about by economic downturn has the potential of luring ex-convicts back to crime and prison that they may access free food and health care such as was the case narrated above or even abdicating their parental responsibilities. This is because sympathetic family members, communities and even government are likely to take over the care of children for an unmarried convicted woman. The finds appear unusual from known literature as according to Brown (2002), McKean and Ransford (2004), Skeem and Peterson, (2010) and Tenibiaje (2013) having family and marital problems, lack of employment, poor education and social stigma highly expose an ex-offender to the likelihood of recidivism. 


\section{Conclusions}

The effects of the challenges that face women returning from prison such as housing, employment, relationships, and mental health affect the individual convicts, their families and communities. Recidivism may also happen when the challenges are not addressed. At the individual level, the women ex-convicts felt that the challenges, especially when unaddressed condemned them to a life of stigma and negative self-image about themselves, hopelessness and poverty, stressful life and discrimination which made them feel suicidal, bitter, and uncertain about life. Families receiving ex-convicts felt that they were unnecessarily carrying an extra burden of sustaining the ex-convicts and their dependents as well as the baggage of stigmatization and discrimination by the community.

Stigmatization, hostility and discrimination are probably the worst reactions to the returnees by the community. Discrimination is seen in social, economic and even religious activities. Communities continually feel insecure, burdened and view them suspiciously leading to a majority of the ex-convicts relocating to places where they are not known. The study findings however indicate low recidivism rates amongst the women ex-convicts interviewed at only $20 \%$. The reasons for recidivism include lack of financial support(poverty), temper, family conflict and separation and singularly taking care of dependent children, peer pressure, greed for money and desire for better life, influence of alcohol and drugs, joblessness and false accusation.

A possible area for further research is on how children are affected by their parents' challenges after incarceration, the effects of these challenges on their upbringing, their behavior and whether it predisposes them to delinquency. This paper has made significant steps in understanding the effects of unaddressed challenges such as unemployment, relationships and housing among others when encountered by female ex-convicts returnees especially in the Kenyan context.

\section{References}

Alexander, M. (2010). The new Jim Crow: Mass incarceration in the age of colorblindness. New York: New Press.

Barlow, H., \& Decker, S. H. (2010). Criminology and public policy : Putting theory to Work. Temple University Press. Retrieved 29 March, 2019, from https://ebookcentral.proquest.com

Bonta , J., Rugge,T., Scott, T., Bourgon, G. \& Yessine, A.K. (2008). Exploring The Black Box Of Communirty Supervision .Journal of Offender Rehabilitation,47:3,248-270,Retrieved 19 February, 2019, from https:doi/org.1080/10509670802134085

Brown, S.L., \& Dowden, C. (2002). The role of substance abuse factors in predicting recidivism :A meta-analysis. Psychology, Crime and Law, 8, 243-264, https://doi.org/10.1080/10683160208401818

Coll, G., Cynthia, and Duff, K. ( 2011). Reframing the Needs of Women in Prison: a Relational and Diversity Perspective. Project report. Wellesley, Mass.: Stone

Cook, P. J., \& Olivier, M. (2013). Lessons from the Economics of Crime: What Reduces Offending? In Machie, S. \& Mastrobuoni, G. MIT Press. Retrieved 29 January, 2019, from https://ebookcentral.proquest.com

Crow, I., \& Semmens, N. (2007). Researching Criminology. Retrieved from https://ebookcentral.proquest.com

Davis, C., Bahr, S.J. \& Ward, C. (2012). The process of offender reintegration: Perceptions of what helps prisoners reenter society. Criminology and Criminal Justice, 13(4):446-469. https://doi.org/10.1177\%2F1748895812454748

Decker, S. H., Ortiz, N., Spohn, C., \& Hedberg, E. (2015). Criminal stigma, race, and ethnicity: The consequences of imprisonment for employment. Journal of Criminal Justice, 43(2), 108-121. https://doi.org/10.1016/j.jcrimjus.2015.02.002

Dodge, M. \& Progrebin, M. R. (2001). Collateral Costs of Imprisonment for Women: Complications of Reintegration. Prison Journal, 81, 42-54. Retrieved 13 September, 2018 from Sage database. https://doi.org/10.1177\%2F0032885501081001004

Dolwick Grieb, S., Crawford, A., Fields, J., Smith, H., Harris, R., \& Matson, P. (2014). The stress will kill you: Prisoner reentry as experienced by family members and the urgent need for support services. Journal of Health Care for the Poor and Underserved, 3, 1183-1200. https://doi.org/10.1353/hpu.2014.0118

Farabee, D., Zhang, S. X., \& Wright, B. (2014). An experimental evaluation of a nationally recognized employment-focused offender reentry program. Journal of Experimental Criminology, 10(3), 309-322. https://doi.org/10.1007/s11292-014-9201-z

Flower, S. M. (2013). Baltimore City jail reentry strategies project: Final report. Retrieved from http://www.baltimorecity.gov/portals/humanservices/downloads/Final\%20Jail\%20Reentry\%20Strategies\%20Report\%2010 .7.2013.pdf

Grommon, E. L. (2013). Prisoner Reentry Programs: Penetrating the Black Box for Better Theory and Practice. LFB Scholarly Publishing LLC. Retrived from https://ebookcentral.proquest.com

Haley, R. M. (1997). Introduction to Criminal Justice. New York: McGraw-Hill.

Harris, M. L. (2015). Returning Home: Intimate Partner Violence and Reentry. LFB Scholarly Publishing LLC. Retrieved 29 January, 2019, from https://ebookcentral.proquest.com

Hattery, A. J. \& Smith, E. (2010). Prisoner Reentry and Social Capital: The Long Road to Reintegration. Lexington Books. Retrieved 29 January, 2019, from https://ebookcentral.proquest.com

Herbert , Claire W. (2014). The ethos of care: Assessing the (Non Legal) Right to property in Detroit (unpublished paper). American Sociological Association Annual Meeting, Chicago, IL. August 22-25.University of Michigan, Ann Arbor.

ILO (1982). Resolution concerning statistics of the economically active population employment, unemployment and underemployment, the Thirteenth International Conference of Labour Statisticians. Retrieved 10 July, 2018, from 
https://www.ilo.org/global/statistics-and-databases/standards-and-guidelines/resolutions-adopted-by-internationalconferences-of-labour-statisticians/WCMS_087481/lang--en/index.htm

ILO. (2015).World Employment and Social Outlook 2015: The Changing Nature of Jobs. International Labour Office. Retrieved 12 February, 2019, from https://ebookcentral.proquest.com

Jupp, Jupp ,V., and Victor R.(1989). Methods of Criminological Research, Routledge. ProQuest Ebook Central. Retrieved 19 June, 2018, from https://ebookcentral.proquest.com

Kaguta, R.J.N. (2014). Rehabilitation of Women in Prison in Kenya: A Focus on Legal and Policy Framework, Process and Practice. (Unpublished doctoral dissertation). University of PAU (UPPA), France.

Kenya National Bureau of Statistics (KNBS). (2018). Statistical Abstract 2018. Nairobi: Author Retrieved 20 May, 2018, from https://www.knbs.or.ke/statistical-abstract-2018/

Kenya National Bureau of Statistics (KNBS). (2018). The 2015/16 Kenya Integrated Household Budget Survey (KIHBS)- Labour Force Basic Report. Nairobi: Author

Kerley, K. R. (2013). Religious faith in correctional contexts. Lynne Rienner Publishers, Inc Retrieved from https://ebookcentral.proquest.com

Kilgore, J. (2015). Understanding mass Incarceration: a people's guide to the key civil rights struggle of our time. The New Press Retrieved from https://ebookcentral.proquest.com

Larner, S. (2017). Pathways from violence: The Impact of Community based Intervention on Offender Reintegration in Gugulethu. South Africa Crime Quarterly, 61,41-55. Retrieved $16 \quad$ January, 2019 from https://www.ajol.info/index.php/sacq/article/view/166049/155484

Losel, F. (2012). Offender Treatment and Rehabilitation: What Works? In Maguire, M., Morgan, \& Reiner, R. (Eds.), The Oxford Handbook of Criminology. 986- 1010

Maruna, S. (2010). Reentry as a Rite of Passage. Punishment \& Society, 1-26. https://doi.org/10.1177/1462474510385641.

McIvor, G. (Ed.) (2004). Women who offend. Jessica Kingsley Publishers Retrieved from https://ebookcentral.proquest.com

Mckean, L. \& Ransford, C. (2004). Current strategies for reducing recidivism. Chicago: Centre for Impact Research. Retrieved 20 May, 2016, from http://www.targetarea.ord/research.doc/recidivismfullreport.pdf

Melissa, L. (2012). Prisoner reentry and reintegration: perspectives of the women involved in Outcare's St John of God Women's Program. Retrieved from https://ro.ecu.edu.au/theses/498

Mumola, C.J. (2000). Incarcerated Parents and their Children. Bureau of Justice Statistics. Special. Report., US Dep. Justice, Washington, DC. Retrieved from https://www.bjs.gov/content/pub/pdf/iptc.pdf

Muthee, J.M. (2020). Challenges Influencing Reentry and Reintegration of Women Ex-Offenders into the Community in Nyeri County, Kenya. (Unpublished doctoral dissertation). Moi University, Eldoret.

Olphen, V., Eliason, M., Freudenberg, N. \& Barnes, M. (2009). Nowhere to go: How stigma limits the options of female drug users after release from jail. Substance Abuse, Treatment, Prevention and Policy, 4,10. 4-10. https://doi.org/10.1186/1747-597x4-10

Pager, D. (2007). Marked: Race, crime, and finding work in an era of mass incarceration. University of Chicago Press. Retrieved from https://ebookcentral.proquest.com.

Petersilia, J. (2005). Hard time: Ex-offenders returning home after prison. Corrections Today, 67(2), 66-71.

Pogorzelski, W., Wolff, N., Pan, K. \& Blitz, C.L. (2005), Behavioral Health Problems, Ex Offender Reentry Policies, and the "Second Chance Act". American Journal of Public Health, $95 \quad$ (10), $1718 \quad-1724$. https://dx.doi.org/10.2105\%2FAJPH.2005.065805

Prison Reform Trust. (2013). Women in Prison .London. Author. Retrieved on 21 July 2018 from http://www.prisonreformtrust.org. Republic of Kenya (1963). Act No. CAP 90: PRISONS. Nairobi: Author. Retrieved from http://www.kenyalaw.org:8181/exist/kenyalex/actview.xql?actid=CAP.\%2090

Republic of Kenya (1963). Act No. CAP 92: Borstal Institutions. Nairobi: Author. Retrieved from http://kenyalaw.org:8181/exist/kenyalex/actview.xql?actid=CAP. $\% 2092$

Republic of Kenya (1963). Act No. CAP 92: Borstal Institutions. Nairobi: Author. Retrieved from http://kenyalaw.org:8181/exist/kenyalex/actview.xql?actid=CAP. $\% 2092$

Schlager, M. (2013). Rethinking the Reentry Paradigm A Blueprint for Action. Durham, NC: Carolina Academic Press.

Sidel̦ska, A. (2014). Housing element as social-economic development of regions (unpublished Doctoral desertation). Jelgava: Latvia University of Agriculture. Retrieved 19 October 9, 2018, from: from https://llufb.llu.lv/dissertation-summary/regionaleconomics/A_Sidelska_prom_darba_kopsavilkums_2014_LLU.pdf

Singh, S.B. (2016). Offender rehabilitation and reintegration: A South African Perspective. Journal of Social Science, 46(1):1-10. https://doi.org/10.1080/09718923.2016.11893506

Skeem, J. \& Peterson, J.P. (2010). Major risk factors for recidivism among offenders with Mental illness. Retrieved from http://www.riskreduction.soceco.vci.edu/wp-content/uploads/2010/12/crimNeedsCSG-Revised-clean.pdf

Snider, L. (2003). Atavistic Man Incarcerates Postmodern Woman. The British Journal of Criminology, 43 (2), $354-378$.

Stohr, M., Walsh, A., \& Hemmens, G. (2009). Corrections. Sage Publications Support and Family Conflict, Justice Quarterly, 32 (2), 337-359. https://doi.org/10.1080\%2F07418825.2013.771207 
Swensen, J. G., Rakis, J., Snyder, M. G., \& Loss, R. E. (2014). Engaging employers and business in the hiring of individuals with criminal records. Journal of Applied Rehabilitation Counseling, 45(4), 15-24. https://doi.org/10.1891/0047-2220.45.4.15

Tenibiaje, D. J. (2013). Educational attainment and peer group influence as predictors of recidivism. International Review of Social Sciences and Humanities, 5(1), 30-37.

Tierney, J. (2009). Key Perspectives in Criminology. McGraw-Hill Education. Retrieved 29 January, 2019, from https://ebookcentral.proquest.com

Travis, J. (2001). But they all come back: Rethinking prisoner reentry. Corrections Management Quarterly, Retrieved 21 June, 2018 , from https://www.ncjrs.gov/pdffiles1/nij/181413.pdf

Triplet, R. \& Upton, L.(2015). Labeling Theory: Past, Present, and Future. In Piquero, A. R. (Ed.). Handbook of Criminological Theory (pp.271-289) Retrieved 29 March, 2019, from https://ebookcentral.proquest.com

WHO (2001). Strengthening mental health promotion. Geneva, World health Organization (Fact sheet, No 220).

Williams, K.S. (2012). Criminology. Oxford: oxford University Press.

World Health Organization (1986). Ottawa Charter for Health Promotion, 1986 Retrieved May 30,2018 from http://www.euro.who.int/_data/assets/pdf_file/0004/129532/Ottawa_Charter.pdf

World Health Organization (2018). Mental disorders. Retrieved May 30, 2018 from https://www.who.int/news-room/factsheets/detail/mental-disorders 